\title{
Aboriginal exploitation of toxic nuts as a late- Holocene subsistence strategy in Australia's tropical rainforests
}

\author{
Åsa Ferrier \\ Archaeology Program, La Trobe University, Melbourne campus, Bundoora, Victoria \\ a.ferrier@latrobe.edu.au \\ Richard Cosgrove \\ La Trobe University, Bundoora, Victoria
}

\section{Introduction}

Human occupation of Sahul (Australia-Tasmania-New Guinea) began about 50,000 years ago, and by 40,000 BP most environments had been colonised (O'Connell and Allen 2008). By this time, people had adapted to the tropics, the arid centre and the glacial areas of Tasmania. In his groundbreaking palynological and palaeoecological studies, Peter Kershaw provided an essential framework within which to examine human responses to changing vegetation and climate variability in Australia. At Lynch's Crater on the Atherton Tableland, Kershaw demonstrated major climatic changes based on the study of pollen and charcoal concentrations fluctuating over the past ca. 120,000 years (Kershaw 1986; Moss and Kershaw 2000). He and his teams identified a date of ca. 45,000 BP for the onset of burning on the Atherton Tableland, through increases in carbon particles around this time (Turney et al. 2001). This evidence was said to support an argument for early peopling of the region, between 45,000 and 55,000 years ago, which also heralded the initial human impacts on Sahul's ecosystems, including the extinction of megafauna. However, despite the evidence for widespread human occupation of Sahul by 40,000 BP, no dates earlier than 8000 years ago have been found in north Queensland's tropical rainforest region. Thus, the present archaeological data run counter to suggestions for the presence of people on the Atherton Tableland ca. 40,000 years ago. However, it is possible there was some Aboriginal occupation on the edge of the rainforest ca. 30,000 years ago (Cosgrove et al. 2007) and further work may reveal late-Pleistocene human 
occupation in the core rainforest area, as has been detected to the north of the study area (Haberle and David 2004; Summerhayes et al. 2010).

Wide-ranging archaeological research in the Atherton-Evelyn Tableland region of north Queensland (Horsfall 1987, 1996; Cosgrove and Raymont 2002; Cosgrove 2005; Cosgrove et al.2007; Ferrier 2010) has shown that the majority of the archaeological material dates to within the past 5000 years, with human occupation initially at very low levels, while it was only within the past 2000 years that occupation intensified. Here, we expand on the current understanding of what appears to be a late-Holocene intensification in site occupation and Aboriginal use of toxic food plants in north Queensland's Wet Tropics Bioregion, with an analysis of the macro-botanical remains excavated from Urumbal Pocket, an open archaeological site on the Evelyn Tableland (Figure 1). We use ethnographic analogy and a modern botanical reference collection to understand past techniques of toxic plant food processing and the identification of archaeological specimens.

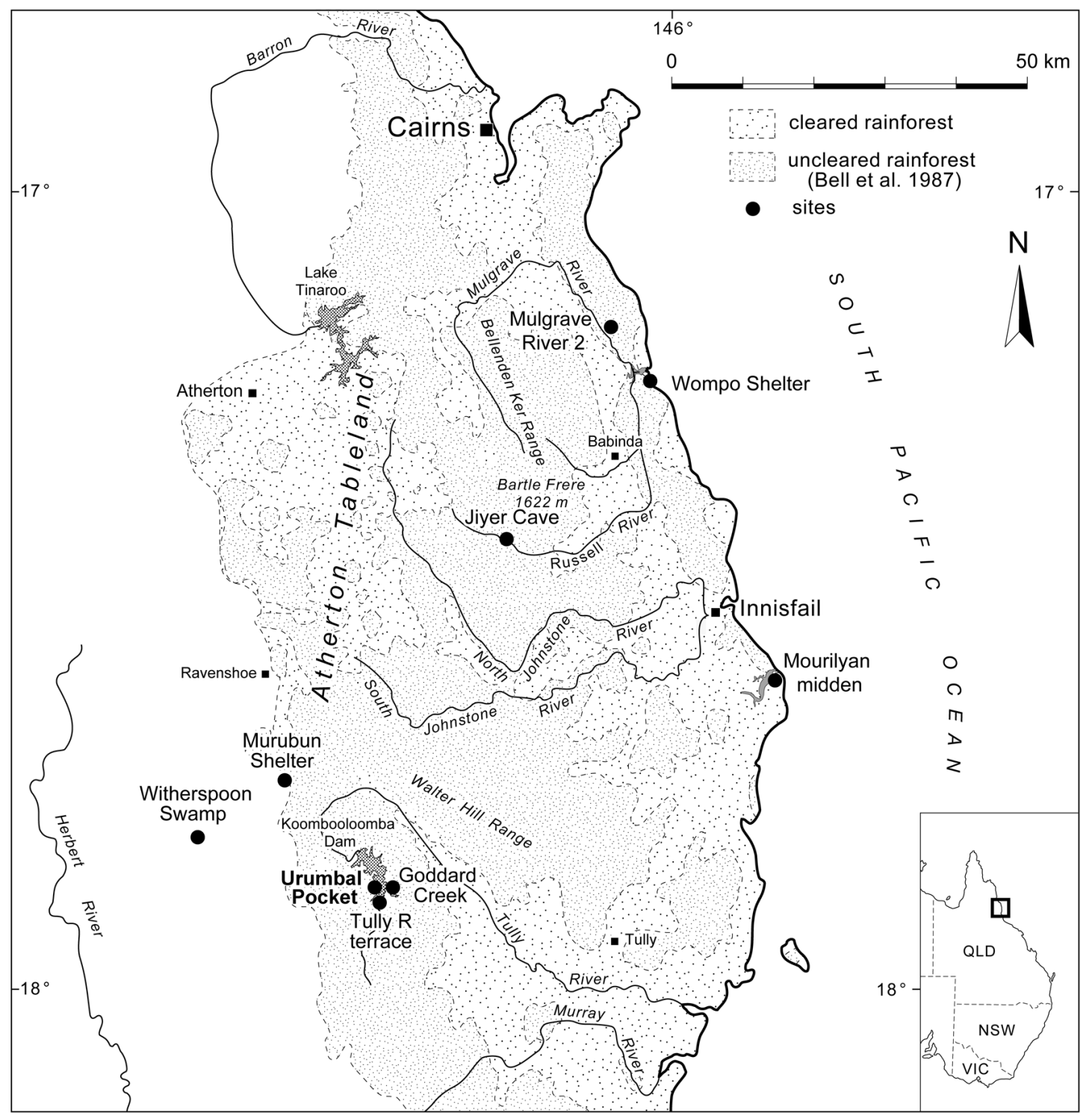

Figure 1. Location of Urumbal Pocket at Koombooloomba Dam and other sites investigated on the Atherton-Evelyn Tableland in Far North Queensland's rainforest region. 


\section{Aboriginal exploitation of toxic foods}

A variety of explanations have been put forward for continent-wide changes in Aboriginal subsistence patterns and site occupation during the mid- to late-Holocene period (Denham et al. 2009). These include social intensification (Lourandos 1997:303, 305) and broad-spectrum resource use (Haberle and David 2004), population increase and ceremonial activities (Beaton 1983, 1985, 1990), large-scale climatic change (Morwood and Hobbs 1995:182) and highintensity El Niño Southern Oscillation (ENSO) activity (Rowland 1999; Cosgrove 2005; Turney and Hobbs 2006; Cosgrove et al. 2007). Unravelling the causes for an increase in the use of poisonous food plants is dependent on a capacity to build solid regional frameworks of archaeological and palaeoecological data that include an understanding of (i) substantial archaeological evidence of ancient plant remains, (ii) site formation and taphonomic processes, (iii) an identification of associated changes in other cultural remains with matching palaeoenvironmental signals, and (iv) commensurate regional site comparisons that have stratigraphically intact dated deposits. Previous studies have argued that the development of toxic plant processing techniques occurred outside Australia and diffused into this country about 4000 to 3000 years ago (Beaton 1983). However, the significant inclusion of tree nuts into rainforest hunter-gatherer diets suggests it was part of a specific regional economic development occurring across Australasia in the Holocene (Denham et al.2009). It has been argued that this development was linked to a much earlier generalist late-Pleistocene subsistence strategy of habitat modification by fire and broad-spectrum plant exploitation. The noted lack of evidence for early plant exploitation may have an underlying taphonomic explanation (Asmussen 2008, 2009, 2010), and unlike faunal remains in some late-Pleistocene sites (Cosgrove and Allen 2001), preservation of organic materials has perhaps hampered the investigations into early plant-food exploitation patterns. We see more consistent evidence in the Holocene from which to make predictions about Aboriginal dietary plant use.

\section{Background}

Aboriginal tropical-rainforest occupation and the use of plant foods by Aboriginal rainforest dwellers was extensively recorded in the early contact period by Europeans such as explorers, botanists, Aboriginal Protectors and naturalists (Lumholtz 1889; Meston 1889; Roth 1900,1901-1910; Coyyan 1918; Mjöberg 1918). Much of the ethno-historical literature has been summarised by Harris $(1975,1978,1987)$, Horsfall $(1987,1990)$ and Pedley $(1992$, 1993), who have discussed Aboriginal foods of the rainforest. From the historical literature, it is apparent that the rainforest provided a wealth of vegetable foods. Historical documents and Aboriginal oral histories demonstrate that plant foods comprised a significant proportion of the Aboriginal rainforest diet, which included the collection, processing and consumption of a large number of rainforest nuts (e.g. Mjöberg 1918:492-494; Pedley 1993; M. Barlow pers. comm. 2004). More than 112 plants have been identified as food sources consumed by Aboriginal rainforest dwellers. Of these, $10 \%$ to $13 \%$ are toxic and require extensive processing (Horsfall 1987; Pedley 1993). Most historical descriptions emphasise specific toxic tree nuts that apparently provided an important food source during the wet season (late November through to March). Experimental work by Pedley (1993:179-180) and Tuechler (2010) has shown that the contribution of toxic nuts to the Aboriginal rainforest diet was significant, being important sources of carbohydrates, protein and fats in various quantities. It has been estimated (Pedley 1993) that toxic nuts comprised around $10 \%$ to $14 \%$ of the diet of rainforest people at the time of Aboriginal-European contact. Their total contribution to the Aboriginal diet in prehistory is unknown, but considering the early ethnographic observations and estimated nutritional 
values, it was probably considerable.

Gold prospector Mick O'Leary made observations in the early 1880s of nut use in the upper Tully River area:

The principal food trees are the koah [yellow walnut], burra [black walnut], bean tree, tchupella [black pine] and a number of smaller varieties; there are also a few vines or tree climbers that at times bear edible fruit. The bean tree is not often used by those people on account of its poisonous nature and the amount of work that is attached to preparing it. The nuts are pared into very thin slices using a piece of sharp quartz, then there is a considerable time that it has to go under the water process and fire before it is fit for consumption. The tchupella is a smaller nut and grows on the trees we know as black pine. When the season is on the food is eagerly sought for by those people and they will travel over miles of country to partake of it. They also grind those nuts, into fire, but it does not require the water treatment, baking in the hot ashes being sufficient. The tchupella is an annual bearer, but is not too plentiful and generally found on the high or tableland country. (Coyyan 1918)

Historical descriptions of Aboriginal toxic-nut exploitation in the rainforest mostly refer to two types of walnut, Beilschmiedia bancroftii (yellow walnut) and Endiandra palmerstonii (black walnut), the 'black pine' nut, Sundacarpus amara, and the black bean, Castanospermum australie. Many of the toxic species utilised by Aboriginal rainforest people are endemic to Australia's Wet Tropics Bioregion (Hyland et al. 2002). The yellow and black walnuts are available for around eight months of the year, mainly over the spring and summer months, and grow at altitudes ranging from $0 \mathrm{~m}$ to $1300 \mathrm{~m}$. The black pine has a considerably shorter fruiting period and is available only between October and December and has a more limited distribution, growing between altitudes of $600 \mathrm{~m}$ and $1200 \mathrm{~m}$ (Cooper and Cooper 2004). The black-bean tree fruits between March and November and grows at altitudes between 0 $\mathrm{m}$ and $840 \mathrm{~m}$ (Cooper and Cooper 2004:204). These varieties of toxic nuts have a high food value, high seasonal abundance and storage potential (both above and below ground), and as a result are sought after by both people and rainforest animals. Yellow walnuts and black pine nuts are eaten by cassowaries and bush rats, while the black walnut is popular with white-tailed rats. A particular attraction of the yellow walnut for humans is that much of the fallen fruit can lie on the ground for a short period without attack from predators. Predators avoid the fallen black bean and black pine nuts, but for a more limited time (Pedley 1993:193), while the black walnut must be collected straight away to prevent competition from the white-tailed rat (Pedley 1993:193). These hard-shelled nuts could be stored for several months below ground for later consumption (Coyyan 1918; Mjöberg 1918; Harris 1975).

Based on historical accounts as well as ethnographic observations, it is possible to reconstruct the processes involved in detoxification. Elaborate lawyer-cane (Calamus australis) baskets were used for the collection of nuts on the ground and lawyer-cane ropes were used for climbing trees to collect fresh nuts (e.g. Roth 1901-1910; Mjöberg 1918). O’Leary observed Aboriginal rainforest people using a sharp piece of quartz to slice toxic nuts on the Tully River, and in other areas of the rainforest region, snail-shell graters were used (Roth 1900; Pedley 1992:51). Earth ovens were used to steam the toxic nuts and other foods, including meat and fish, sometimes lining the pit with river cobbles as well as ginger leaves, placing the nuts in the pit and covering them up with more leaves, and finally placing hot coals on top. Following this baking and steaming procedure, the nuts were cracked open using a small cobble as a nutcracking stone. Lastly, the grated pulp was put in lawyer-cane dilly bags and leached for two to three days in a small running creek. Once leached of their toxins, the pulp was chewed and 
formed into a paste that was eaten raw, and later in the contact period, Aboriginal rainforest people made it into 'Johnny cakes', or flat cakes that were baked on hot coals (Coyyan 1918; Mjöberg 1918; Pedley 1992). What remains in the archaeological record are the carbonised fragments of the hard layer of endocarp that enclose a single seed (nut).

\section{Archaeological investigations}

The archaeological open site at Urumbal Pocket is located on a flat spur, high on a bank above the original course of the Tully River (Figure 2).

Urumbal Pocket is a series of Eucalyptus patches among rainforest, bordering a stretch of the upper Tully River. In total, six $1 \mathrm{~m}$ x $1 \mathrm{~m}$ pits were excavated at the site to investigate the

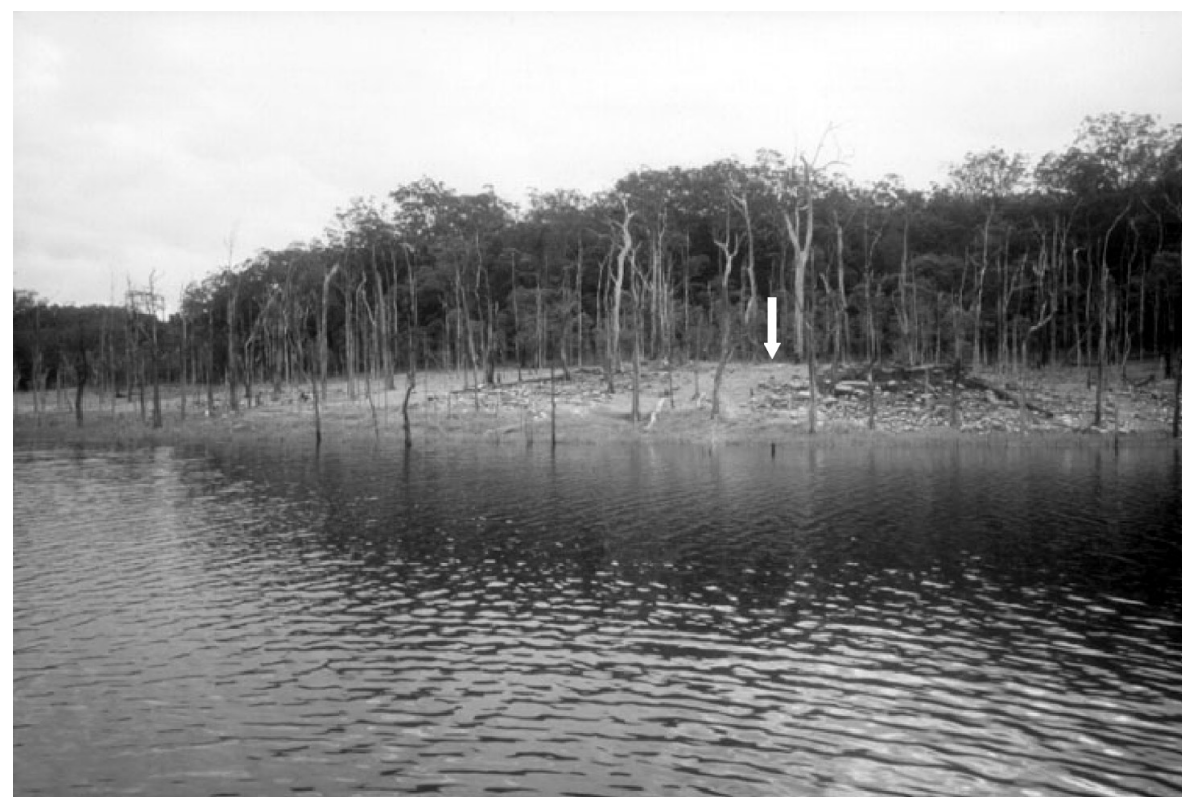

Figure 2.

The archaeological open site at Urumbal Pocket, located on a flat spur, high on a bank above the original course of the Tully River.

density of archaeological remains and the age and stratigraphy of the site, as well as to establish the spatial distribution of cultural materials. Two main stratigraphic units are distinguished on the basis of soil colour and structure - an upper dark humic layer, with an underlying lighter layer (Figure $3)$.

The soil type is common in the area and defined as Yellow Kandosol (McKenzie et al.2004:246247). Unit 1 consists of an artefact-rich black loam, with a Munsell ranging from 10YR1/7 in the top layers to $7.5 \mathrm{YR} 4 / 6$ in the bottom layers. The sediments in Unit 1 can be described as a homogeneous and unconsolidated sandy loam deposit with fine grit throughout, derived from the surrounding organic soil. A transition layer separates Unit 1 and 2 (7.5YR 3/2) and consists of a light brown gritty soil that is distinguished by some orange mottling. Its top starts at a depth of $40 \mathrm{~cm}$ and is approximately $10 \mathrm{~cm}$ thick. Sediments in Unit $2(7.5 \mathrm{YR} \mathrm{4/6)} \mathrm{become} \mathrm{increasingly}$ gritty and are less homogeneous with depth, with particles from the decomposing granite bedrock becoming incorporated into the soil.

\section{Chronology}

Charcoal was recovered from all squares excavated. Seventeen radiocarbon dates were obtained from in situ samples of charcoal recovered during the excavations (Table 1). The dates show a good chronological order, suggesting that the site is relatively undisturbed. The earliest dates at Urumbal Pocket, $7445 \pm 68 \mathrm{BP}(8273 \pm 67 \mathrm{cal} \mathrm{BP}$ [Wk-13578]) and $7212 \pm 46 \mathrm{BP}(8052 \pm 65 \mathrm{cal}$ 

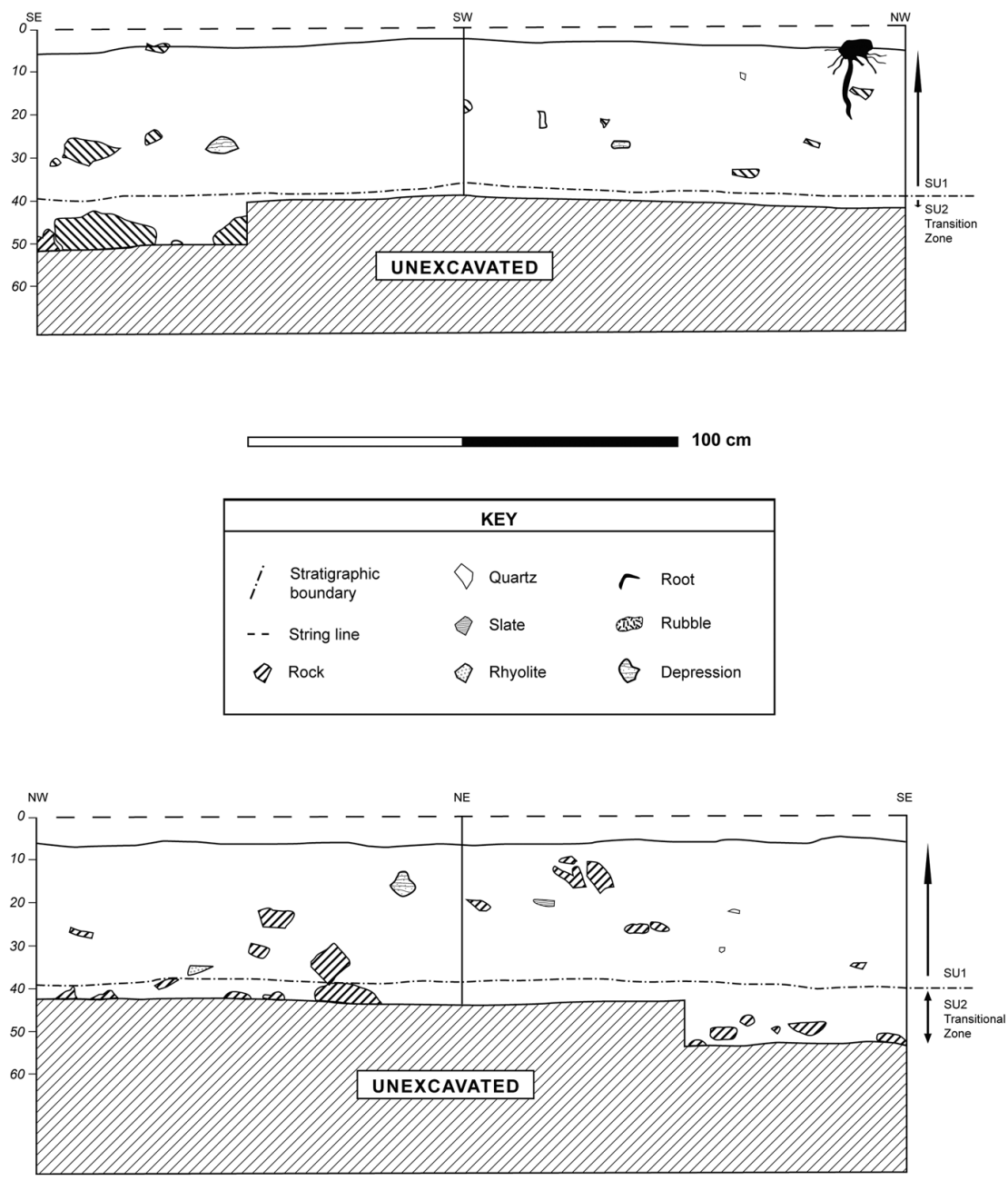

Figure 3. Stratigraphic sections in square $Z 3$ at Urumbal Pocket.

BP [Wk-13571]) are from charcoal found in the lower spits of Unit 2 together with a small number of quartz artefacts. The dates coincide with an initial period of Holocene rainforest expansion, and correspond with increases in microscopic charcoal in the pollen record (Haberle 2005; Cosgrove et al. 2007). A further six AMS dates (bold in Table 1) were obtained from in situ diagnostic endocarp fragments. The dates on the nutshell fragments broadly correlate with the dates on the charcoal samples. One excavated Lauraceae endocarp fragment, a yellow walnut (Beilschmiedia bancroftii) or a black walnut (Endiandra palmerstonii), was submitted for ${ }^{14} \mathrm{C}$ analysis. The fragment returned a date of $1585 \pm 40 \mathrm{BP}$ (uncalibrated age; OZJ718) and is consistent with evidence for toxic plant use from other archaeological sites in the region (Horsfall 1987:268; Cosgrove et al. 2007). The dated Lauraceae fragment from Urumbal Pocket provides a minimum age for the appearance of toxic nut processing in the rainforest.

Table 2 below shows how the grouping of radiocarbon dates from Urumbal Pocket suggests three phases of Aboriginal occupation at Urumbal Pocket, where ca. $70 \%$ of the dates are younger than 1500 years. The three occupation phases are correlated with increasingly high numbers of cultural materials through time. Some mixing of the deposits in Unit 1 may be related to increased human activity at the site in the past 1000 years. The chronology points to very low intensity initial site use around 8000 years ago, with a hiatus in site use from around $7000 \mathrm{BP}$ until $5000 \mathrm{BP}$. The evidence points to an occasional use of the site between $5000 \mathrm{BP}$ and $2000 \mathrm{BP}$. At the end of Phase 2 (transition zone), cultural materials start to increase, and Phase 3, dating from around $2000 \mathrm{BP}$ to the late 1800s, is rich in cultural materials. Thousands of stone artefacts, small amounts of ochre and plant remains were recovered from these upper layers. 
Table 1. Conventional and calibrated radiocarbon dates for Urumbal Pocket.

\begin{tabular}{|c|c|c|c|c|c|c|}
\hline Square & Spit & Material dated & $\begin{array}{l}\text { Uncalibrated } \\
\text { age }\end{array}$ & $\begin{array}{l}\text { Calendric age } \\
\text { cal BP }\end{array}$ & $\begin{array}{l}68 \% \text { range } \\
\text { cal BP }\end{array}$ & Code \\
\hline $\mathrm{A} 2$ & 3 & charcoal & $514 \pm 51 \mathrm{BP}$ & $569 \pm 48$ & $520-617$ & Wk-11341 \\
\hline $\mathrm{A} 2$ & 5 & charcoal & $1045 \pm 51 \mathrm{BP}$ & $980 \pm 51$ & $929-1031$ & Wk-11342 \\
\hline $\mathrm{A} 2$ & 8 & charcoal & $3339 \pm 66 \mathrm{BP}$ & $3579 \pm 82$ & $3497-3661$ & Wk-11343 \\
\hline $\mathrm{A} 2$ & 10 & charcoal & $4887 \pm 93 \mathrm{BP}$ & $5627 \pm 111$ & $5516-5738$ & Wk-11344 \\
\hline 02 & 7 & charcoal & $422 \pm 40 \mathrm{BP}$ & $449 \pm 62$ & $387-511$ & Wk-13566 \\
\hline 02 & 10 & charcoal & $2201 \pm 46 \mathrm{BP}$ & $2229 \pm 69$ & $2160-2298$ & Wk-13567 \\
\hline S2 & 13 & charcoal & $1497 \pm 34 \mathrm{BP}$ & $1381 \pm 30$ & $1351-1411$ & Wk-13568 \\
\hline S2 & 15 & charcoal & $1660 \pm 44 \mathrm{BP}$ & $1573 \pm 54$ & $1581-1627$ & Wk-13569 \\
\hline V5 & 7 & charcoal & $1581 \pm 41 \mathrm{BP}$ & $1472 \pm 47$ & $1424-1519$ & Wk-13570 \\
\hline V5 & 9 & charcoal & $7212 \pm 46 \mathrm{BP}$ & $8052 \pm 65$ & 7987-8117 & Wk-13571 \\
\hline V8 & 6 & charcoal & $1374 \pm 39 \mathrm{BP}$ & $1304 \pm 21$ & $1283-1325$ & Wk-13572 \\
\hline V8 & 8 & charcoal & $2628 \pm 51 \mathrm{BP}$ & $2762 \pm 34$ & $2728-2796$ & Wk-13573 \\
\hline v8 & 9 & endocarp & $1585 \pm 40 \mathrm{BP}$ & $1474 \pm 47$ & $1427-1521$ & 0ZJ718 \\
\hline Z3 & 2 & charcoal & $190 \pm 37 \mathrm{BP}$ & $156 \pm 122$ & $33-278$ & Wk-13574 \\
\hline $\mathbf{Z 3}$ & 4 & endocarp & $470 \pm 60 \mathrm{BP}$ & $502 \pm 44$ & $457-546$ & 0zJ719 \\
\hline $\mathbf{Z 3}$ & 5 & endocarp & $850 \pm 40 \mathrm{BP}$ & $778 \pm 51$ & $727-829$ & 0zJ720 \\
\hline 23 & 7 & endocarp & $720 \pm 40 \mathrm{BP}$ & $676 \pm 21$ & 655-697 & $0 Z J 721$ \\
\hline Z3 & 8 & charcoal & $672 \pm 39 \mathrm{BP}$ & $622 \pm 45$ & $577-667$ & Wk-13575 \\
\hline$Z 3$ & 11 & charcoal & $1244 \pm 40 \mathrm{BP}$ & $1181 \pm 64$ & $1117-1245$ & Wk-13576 \\
\hline $\mathbf{Z 3}$ & 11 & endocarp & $1605 \pm 40 \mathrm{BP}$ & $1486 \pm 51$ & $1434-1537$ & 0zJ722 \\
\hline 23 & 13 & endocarp & $1595 \pm 40 \mathrm{BP}$ & $1480 \pm 48$ & $1431-1528$ & $0 Z$ Jj23 \\
\hline Z3 & 14 & charcoal & $2143 \pm 48 \mathrm{BP}$ & $2169 \pm 104$ & $2065-2273$ & Wk-13577 \\
\hline Z3 & 16 & charcoal & $7445 \pm 68 \mathrm{BP}$ & $8273 \pm 67$ & $8205-8340$ & Wk-13578 \\
\hline
\end{tabular}

\section{The plant assemblage}

The plant assemblage from Urumbal Pocket consists for the most part of robust endocarp fragments, generically referred to as nutshells. The plant remains are highly fragmented, both as a result of nut-cracking during processing and probably also from human activities at the site, such as trampling and cleaning activities. A small number of complete and incomplete seeds with diagnostic features were also recovered. All of the botanical remains are carbonised inert charcoal, which has allowed for their survival in the archaeological record (Horsfall 1987, 1990). It is not yet clear how the plant remains became burnt, but experiments show that nutshell fragments put on coals produced from a small $\log$ fire burn fast and disintegrate to ash. Nutshell charring is therefore most likely to have taken place in a low oxygen environment and their survival is possibly due to anaerobic carbonisation during the steaming and baking of the nuts. This step in the detoxification process has been described as 'nuts roasted in hot ash' (Mjöberg 1918:494), which suggests that the nuts came in direct contact with hot ash and as a result perhaps became burnt. A second explanation is that the nutshells were incorporated into coals in dying fires as waste products during cleaning up activities at the site. Further experimental work may reveal an explanation of their survival in the archaeological record.

\section{Creating a modern reference collection}

To facilitate identification of the excavated nutshell fragments, modern samples of yellow 
Table 2. Chronologically ordered uncalibrated radiocarbon dates from Urumbal Pocket, grouped into three phases of site use; about $70 \%$ date to more recently than $2000 \mathrm{BP}$ (bold dates indicate transition zone).

\begin{tabular}{|c|c|c|}
\hline \multicolumn{2}{|c|}{ Stratigraphic Unit 2} & \multirow{2}{*}{$\begin{array}{c}\text { Stratigraphic Unit } 1 \\
\text { Phase } 3 \\
\text { Intensive use after } \\
\text { ca. } 2000 \mathrm{BP}\end{array}$} \\
\hline $\begin{array}{c}\text { Phase } 1 \\
\text { Low level use } \\
\text { ca. } 8000-7000 \text { BP }\end{array}$ & $\begin{array}{c}\text { Phase } 2 \\
\text { 0ccasional use } \\
\text { са. } 5000-2000 \text { BP }\end{array}$ & \\
\hline \multicolumn{3}{|l|}{$7445 \pm 68 \mathrm{BP}$} \\
\hline \multicolumn{3}{|l|}{$7212 \pm 46 \mathrm{BP}$} \\
\hline & $4887 \pm 93 \mathrm{BP}$ & \\
\hline & $3339 \pm 66 \mathrm{BP}$ & \\
\hline & $2628 \pm 51 \mathrm{BP}$ & \\
\hline & $2201 \pm 46 \mathrm{BP}$ & \\
\hline & $2143 \pm 48 \mathrm{BP}$ & \\
\hline & & $1605 \pm 40 \mathrm{BP}$ \\
\hline & & $1595 \pm 40 \mathrm{BP}$ \\
\hline & & $1585 \pm 40 \mathrm{BP}$ \\
\hline & & $1581 \pm 41 \mathrm{BP}$ \\
\hline & & $1497 \pm 34 \mathrm{BP}$ \\
\hline & & $1374 \pm 39 \mathrm{BP}$ \\
\hline & & $1244 \pm 40 \mathrm{BP}$ \\
\hline & & $1045 \pm 51 \mathrm{BP}$ \\
\hline & & $850 \pm 40 \mathrm{BP}$ \\
\hline & & $720 \pm 40 \mathrm{BP}$ \\
\hline & & $672 \pm 39 \mathrm{BP}$ \\
\hline & & $514 \pm 51 \mathrm{BP}$ \\
\hline & & $470 \pm 60 \mathrm{BP}$ \\
\hline & & $422 \pm 40 \mathrm{BP}$ \\
\hline & & $190 \pm 37 \mathrm{BP}$ \\
\hline
\end{tabular}

and black walnuts, as well as black pine nuts, were collected and brought back to the laboratory for comparison. The black bean does not contain a thick endocarp layer and as a result was eliminated as a possible candidate. Samples of modern yellow and black walnuts and black pine nuts were collected from underneath trees located in the study area and in locations on the Atherton-Evelyn Tableland with a vegetation structure similar to pre-European times. This ensured that the modern reference collection was representative, taking into account any size variation within the modern and archaeological plant assemblages. The morphological features of 22 modern samples of yellow and black walnut and five modern samples of black pine nut were recorded. These attributes were then used as a guide to compare and contrast attributes recorded on the archaeological plant material.

\section{Methods applied in the analysis}

All nutshell fragments greater than $10 \mathrm{~mm}$ in maximum dimension and with distinctive surface features visible to the naked eye were selected for analysis. Surface structures were also compared using a standard binocular microscope (7-40 X). The significant morphological features of modern walnuts and black pine nuts recorded were (i) shape, (ii) size, (iii) thickness of the endocarp wall, and (iv) surface structures. The results from recording these morphological features on the modern samples were compared with results from analysis of the archaeological nutshell fragments (Table 3). In the modern samples, yellow and black walnuts are spherically shaped. The main surface feature on the black walnut is a pointed and sharp apex with an opposite blunt base, and on the yellow walnut the apex and base both have sharp protrusions (Figure 4). 
Black pine nuts are also spherical, but are slightly more oblong, smaller and lack the pointed ends. In the first instance, large curved endocarp fragments and fragments with distinctly pointed or swollen ends were selected for further analysis and identification (Figure 5).

Some size variability in the modern walnut samples was observed, similar to that recorded

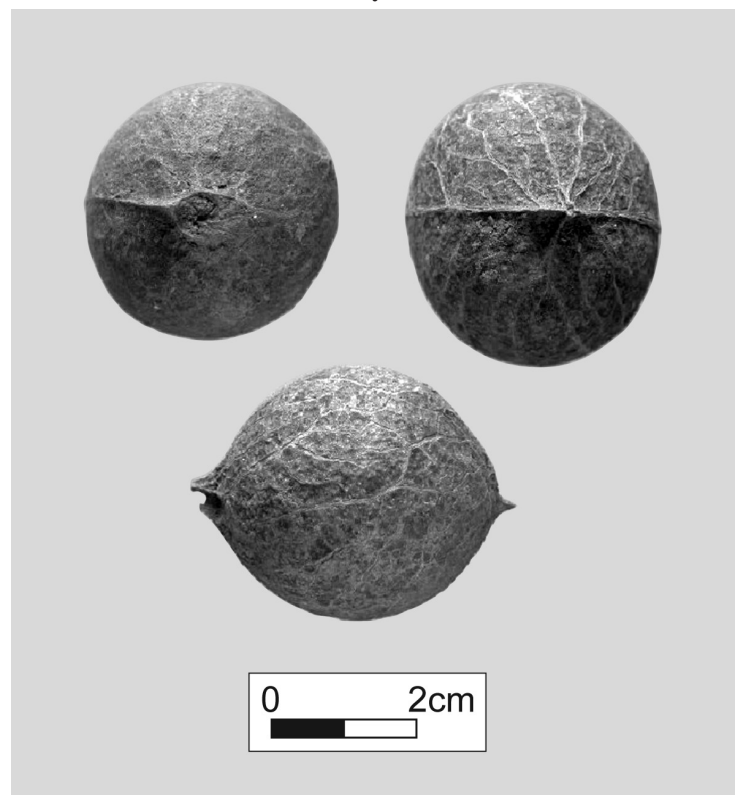

Figure 4. Distinctive features on a modern yellow walnut.

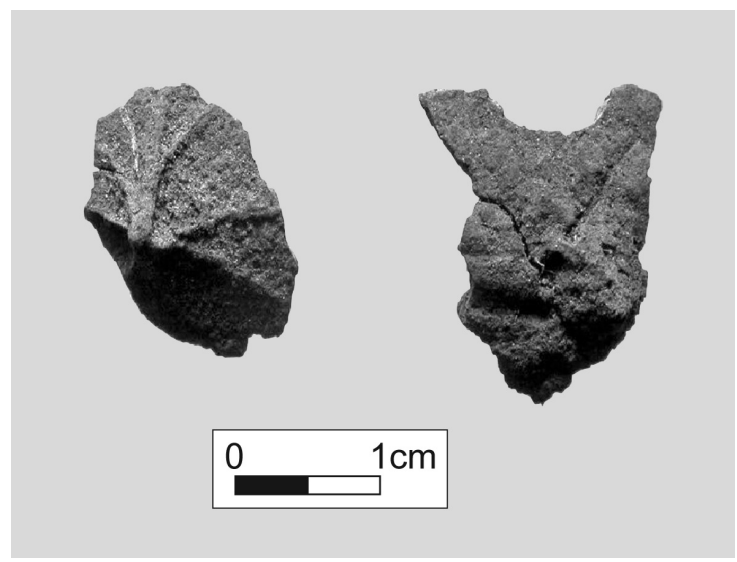

Figure 5. Excavated nutshell fragments showing preserved parts of pointed apex and surface ornamentations. in the botanical literature on tropical rainforest plants (Cooper and Cooper 2004:242). Modern black pine nut samples were all relatively small $(20-25 \mathrm{~mm})$ and fell outside the modern walnut size range (28-50 mm). A circle template was used to measure large, curved endocarp fragments in the archaeological assemblage so that the complete modern samples could be compared. This enabled an estimation of the size of the nut, including the complete seed surrounded by the endocarp layer. The modern sample sizes were used to assess potential endocarp shrinkage during the carbonising process that could result in erroneous identifications. Those samples that matched the modern walnut size were selected for further analysis. At this point, fragments significantly smaller than the modern range of walnuts and without any other morphological indicators such as endocarp thickness or surface ornamentations were eliminated from the analysis and recorded as unidentified fragments. Black pine nuts are outside the walnut size range and due to their lack of diagnostic morphological features other than size and shape, it was difficult to make a positive identification. The thickness of the endocarp wall was measured in millimetres using callipers, with the aim of investigating whether or not fragments shrunk in the process of carbonisation, potentially making identification ambiguous (Figure 6).

The endocarp walls of the modern black pine nut were consistently thinner than those of the walnuts, making them susceptible to breakage, and difficult to identify among the archaeological assemblage. Although some thin pieces of endocarp with a smaller circumference were tentatively attributed to black pine, further microscopic analysis of cell structure would be required for a conclusive identification. Surface features were carefully examined and recorded, following Anderberg (1994:9). Endocarp fragments preserving a complete or part of a pointed apex were easily identified to either black or yellow walnut. Other surface structures recorded on modern samples were their relative smoothness, the presence of veins, and surfaces with foveate (pitted), rough and ribbed ornamentations.

A number of complete and incomplete seeds were also recovered in the archaeological deposits. The excavated seeds were identified by comparison with modern reference material held at CSIRO's tropical herbarium in Atherton and with samples collected in the field. 
Table 3. Morphological features recorded on modern walnuts and black pine nuts compared with results from analysis of the archaeological nutshell fragments.

\begin{tabular}{|c|c|c|c|c|}
\hline Attribute & $\begin{array}{l}\text { Modern yellow } \\
\text { and black walnut }\end{array}$ & $\begin{array}{l}\text { Excavated nutshell } \\
\text { fragment }\end{array}$ & $\begin{array}{l}\text { Modern } \\
\text { black pine }\end{array}$ & $\begin{array}{l}\text { Excavated nutshell } \\
\text { fragment? }\end{array}$ \\
\hline Shape & globose & curved & $\begin{array}{l}\text { globose but slightly } \\
\text { more oblong than } \\
\text { walnuts }\end{array}$ & slightly curved \\
\hline Size & $28-50 \mathrm{~mm}$ & $25-50 \mathrm{~mm}$ & $20-25 \mathrm{~mm}$ & $<25 \mathrm{~mm}$ \\
\hline $\begin{array}{l}\text { Endocarp } \\
\text { thickness }\end{array}$ & $1-3 \mathrm{~mm}$ & $1-3 \mathrm{~mm}$ & $0.5-1 \mathrm{~mm}$ & $0.5 \mathrm{~mm}$ \\
\hline Surface ornamentation & $\begin{array}{l}\text { sharp protrusions } \\
\text { on one or two ends, } \\
\text { smooth surface } \\
\text { with veins or ribbed } \\
\text { structures }\end{array}$ & $\begin{array}{l}\text { sharp protrusions on } \\
\text { ends, smooth surface } \\
\text { with veins, pitted or } \\
\text { rough structures }\end{array}$ & $\begin{array}{l}\text { lack protrusions on } \\
\text { ends, overall smooth } \\
\text { surface }\end{array}$ & smooth surface \\
\hline
\end{tabular}

A number of these were identified as Sapotaceae, genus Pouteria (B. Grey pers. comm. 2006). Pouteria spp. seeds have a number of key distinguishing features. They are ovate with one or two pointed ends and have a smooth surface with a groove running down the centre of the body (Figure 7).

The interpretation that Pouteria species were used and deposited in the sites by humans cannot be supported by reference to ethnographic analogy, although another variety, Pouteria sericea, is considered 'bush tucker' in the field guides to vegetation of dry tropical areas in Queensland (Brock 2005:287). In this case, it is the fleshy pericarp that is consumed by humans. Another type of seed found in the archaeological deposits is a small, round to slightly oval seed, between $10 \mathrm{~mm}$ and $14 \mathrm{~mm}$ in diameter, with distinct surface ornamentations. The seed is enclosed within a thin, wrinkled and woody endocarp (Figure 8). This type of seed has tentatively been identified as belonging to the Elaeocarpaceae and is probably one of the quandong species (B. Hyland pers. comm. 2006). The use of other Elaeocarpus species by rainforest dwellers was recorded in the contact period, for example Elaeocarpus bancroftii, the Johnstone River almond (Harris 1975:39-43).

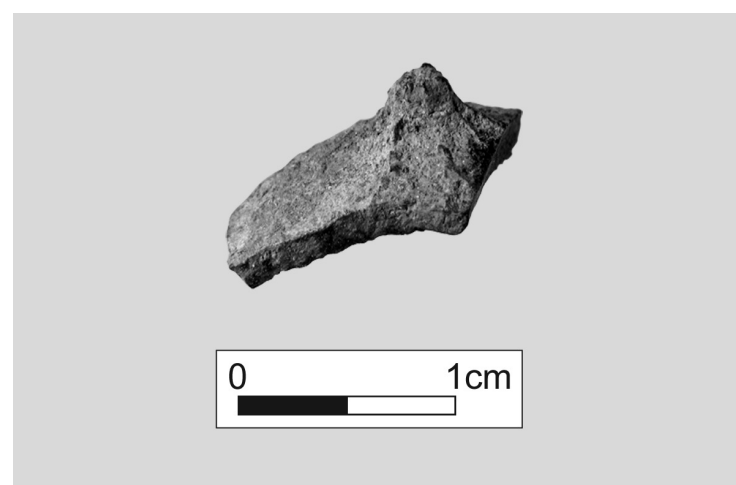

Figure 6. Walnut endocarp fragment showing characteristic morphological features discussed in the text.

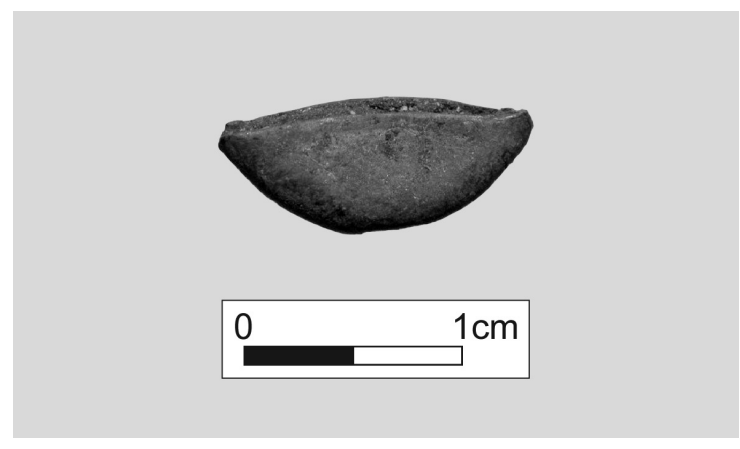

Figure 7. Excavated Pouteria euphlebia (fam. Sapotaceae) seed, showing characteristic groove running down the centre of its body. 


\section{Potential limitations of the data}

Investigations into past plant use by humans must include examinations of taphonomy and site formation processes in order to understand their vectors of introduction (Smith 1982, 1996; Clarke 1985, 1988; McConnell and O'Connor 1997; Wallis 2001, 2003; Martinoli and Jacomet 2004). Thus, discriminating between cultural and natural plant accumulations is important to the interpretation of plant evidence found at archaeological sites in general (Beck

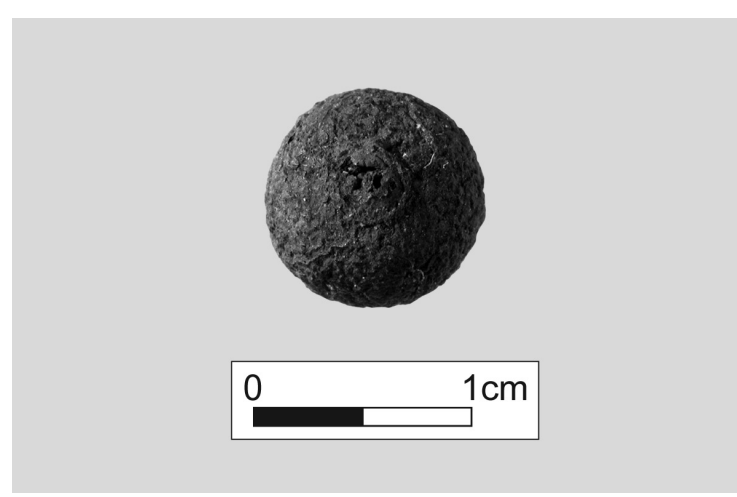

Figure 8. Excavated seed tentatively identified as belonging to the Elaeocarpaceae family.

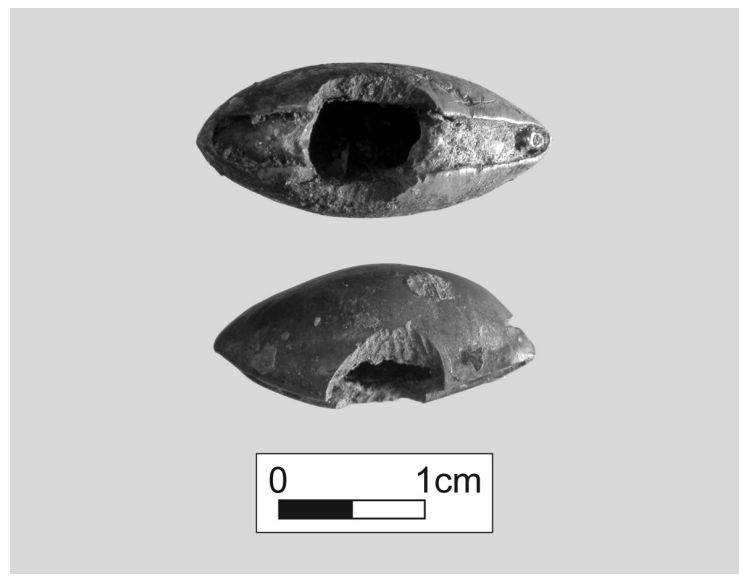

Figure 9. Rat gnaw marks on modern samples of Pouteria spp.

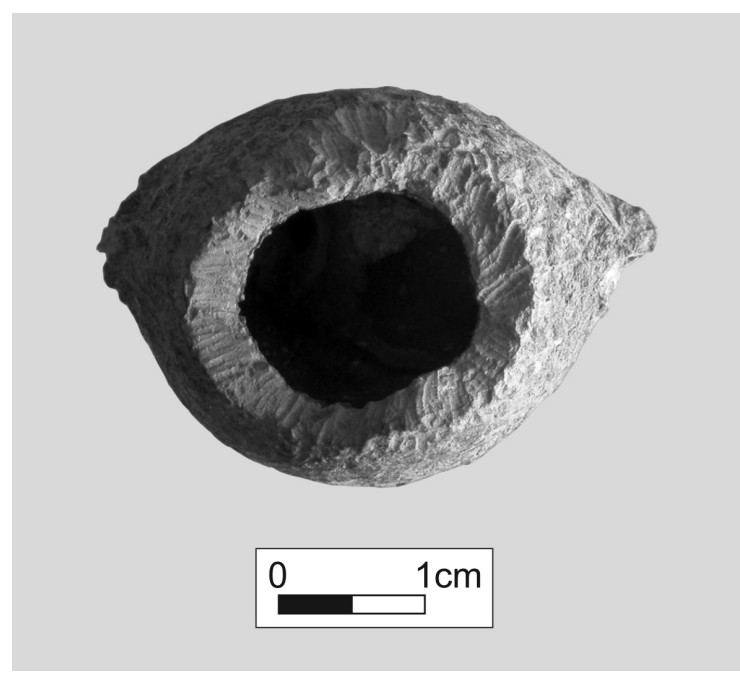

Figure 10. Rat gnaw marks on a modern yellow walnut, Beilschmedia bancroftii. et al.1989). It has been suggested that good indications of the past cultural use of a plant are (i) its presence in high concentrations, (ii) a continuous presence through time in cultural deposits, (iii) similar patterns within a range of taxa, and (iv) the nature of the preservation of the remains (Minnis 1981). Criteria to consider when trying to discriminate between cultural and natural plant accumulations in the archaeological record include radiocarbon dating of plant remains, comparison of species represented in cultural soils with those in adjacent non-cultural soils, and a presence of high concentrations and good preservation of identifiable elements, particularly those that are burnt and charred (Keepax 1977:226228; Minnis 1981). The plant remains excavated from Urumbal Pocket fulfil these criteria. However, to further assist in the identification of cultural and natural plant accumulations in the archaeological record at Urumbal Pocket, the spatial distribution of plant remains was tested for in a series of shovel tests dug in a $150 \mathrm{~m}$ forest transect perpendicular to the site. Some wood charcoal was collected, but no nutshell or other cultural materials were identified in the pits. This suggests that adjacent noncultural soils contain no charred nutshells and reduces the possibility that the botanical remains were deposited at the site from natural fires and subsequent slope wash.

In addition, none of the identified species grow within the immediate vicinity of the site. The surrounding vegetation at Urumbal Pocket is currently dominated by eucalypts. Several dates on charcoal from soil pits near the excavation suggest fire has influenced the vegetation for the last 8000 years (7181 $\pm 30 \mathrm{BP}=7988 \pm 23 \mathrm{cal} \mathrm{BP}$ [Wk-28722]), suggesting that the archaeological plant 
remains are not the result of nuts and seeds falling into the site from overhanging rainforest vegetation. A further indicator that strongly supports the hypothesis that humans discarded the plant remains is the lack of evidence for animal consumption on the archaeological plant remains. Rodents and cockatoos fed on nuts and seeds of the species identified archaeologically, leaving distinct gnaw marks such as those in Figures 9 and 10.

Thus, the evidence supports the notion that the carbonised plant remains found in the Urumbal Pocket excavations were brought to the site by Aboriginal people. To summarise, the evidence for this is:

1. Aboriginal people reportedly used the species represented archaeologically, according to oral traditions and ethno-historical documents.

2. There is a narrow range of species represented.

3. The plant remains are charred.

4. Pits dug outside the site contain no charred plant remains.

5. The remains have not been chewed by rats and other animals.

\section{Results}

More than 9100 pieces of plant remains, weighing a total of $422.7 \mathrm{~g}$, were recovered from the Urumbal Pocket archaeological excavations. Of these, more than $90 \%$ are unidentified carbonised endocarp fragments fewer than $10 \mathrm{~mm}$ in size. The remainder consists for the most part of diagnostic endocarp fragments greater than $10 \mathrm{~mm}$, in addition to a number of complete and partially complete seeds. All of the identified plant remains are from Unit 1 , and account for $5.3 \%$ of the total plant assemblage. An MNI of 86 pieces of endocarp is derived from the two species of toxic walnut, either Beilschmiedia bancroftii or Endiandra palmerstonii. At least another 312 fragments are curved pieces of endocarp from a large type of fruit (greater than 25-30 $\mathrm{mm}$ in diameter). Given that the estimated size, endocarp wall thickness and surface ornamentations of the partial remains are consistent with features recorded on modern walnuts, there is a strong possibility that these are also walnut fragments. Modern and archaeological samples showed no significant difference in the size of the nuts or endocarp wall thickness and it is concluded that no

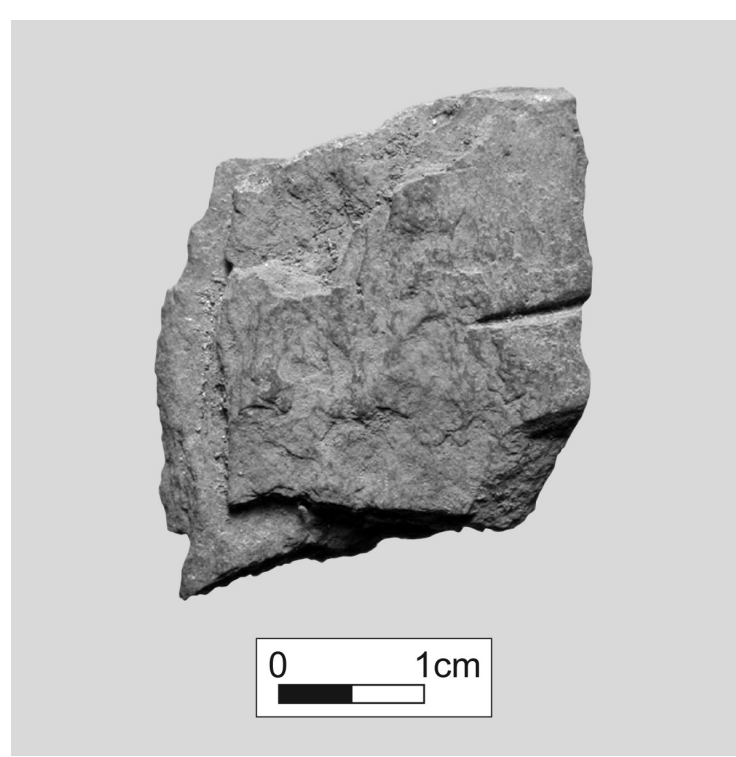

Figure 11. Fragment of incised slate grinding stone recovered from the Urumbal Pocket excavations. major shrinkage occurred to the fragments at the time they were burnt, thus eliminating the possibility of misidentification. Starch grain analysis was carried out on an excavated fragment of an incised slate grinding stone (UP/A2/SP5/1022) from Urumbal Pocket (Figure 11) to provide evidence for what types of plants were being processed on a particular stone artefact (Cosgrove et al. 2007; Field et al. 2009). 
These stone tools, sometimes referred to as graters, are restricted to Far North Queesnsland's rainforest region. The results showed that the grooves on incised grinding stones act as 'residue traps' and preserve micro-fossils such as starch and phytoliths. Starch recovered from the fragment excavated at Urumbal Pocket was identified to yellow walnut, indicating on-site processing (Cosgrove et al. 2007:164; Field et al. 2009). The results support an interpretation that toxic starchy seeds were being exploited at Urumbal Pocket, and are consistent with the identification of carbonised nutshells of the yellow walnut (Beilschmiedia bancroftii). The remaining 98 identified specimens, which consist of complete and partly complete seeds, have been identified to Sapotaceae, and more specifically to varieties of Pouteria spp. A small round seed is also represented at the two sites and has been tentatively identified to Elaeocarpaceae, probably one of the quandong species. Neither of these two species has been previously identified as economically important, or historically documented as a food source by Aboriginal rainforest people.

Results indicate that toxic walnuts were being processed at Urumbal Pocket, a detoxification process that takes several days. It is likely that Aboriginal people stayed at the site more than one night during each visit, assuming that the occupants had the same toxic-nut processing techniques as historically recorded and that they did the whole processing cycle on site.

Table 4. Distribution of carbonised plant remains in grams per square and per composite spit in Analytical Units 1 and 2.

\begin{tabular}{|l|l|l|}
\hline Square & $\begin{array}{l}\text { Analytical } \\
\text { Unit } 1\end{array}$ & $\begin{array}{l}\text { Analytical } \\
\text { Unit 2 }\end{array}$ \\
Weight $(\mathbf{g})$ & Weight $(\mathbf{g})$ \\
\hline A2 & 75.8 & 1.5 \\
\hline Z3 & 130.5 & 10.1 \\
\hline V5 & 49.7 & 0.5 \\
\hline V8 & 93.4 & 0.9 \\
\hline S2 & 45.1 & 2.8 \\
\hline 02 & 12.0 & 0.4 \\
\hline Total & 406.5 & 16.2 \\
\hline
\end{tabular}

Despite the burning process associated with nut processing, our analysis has shown that it is possible to specifically identify a small proportion of the excavated macro-fossils from the archaeological record. We have shown that these nuts belong to the Lauraceae family; i.e. the yellow (Beilschmedia bancroftii) and black (Endiandra palmerstonii) walnuts. Two other types of seeds recovered in the excavations were identified to a variety of Pouteria spp. and a variety of Elaeocarpaceae. Neither is referred to in the ethno-historical literature or remembered by Aboriginal elders as a food source in the recent past (M. Barlow pers. comm.). In contrast, use of Sundacarpus amara (black pine) as a food source in the contact period was observed and documented (e.g. Mjöberg 1918). Black pine could not with any certainty be identified in the plant macrofossil assemblage. It is possible that black pine nuts are too fragile to survive site formation processes, although it is also possible that, since the trees only produce nuts during a short period between October and December, the site was occupied at other times.

\section{Long-term Aboriginal plant use at Urumbal Pocket}

The temporal distribution of plant remains was assessed in the two Analytical Units. Table 4 shows that most of the plant remains were excavated from Unit 1. 
Nutshell fragments from Unit 2 are characteristically smaller in size and lack any clear diagnostic features. However, it demonstrates that carbonised nutshells can survive in older deposits and that Aboriginal people were most likely exploiting rainforest environments and bringing rainforest plant foods to the site before 2000 years ago, as unidentified nutshell fragments were recovered in association with stone artefacts and charcoal in layers radiocarbon dated to ca. 2500 years old. At Urumbal Pocket, numbers of plant remains peak in layers dated to between $800 \mathrm{BP}$ and $400 \mathrm{BP}$, a time period also associated with high stone-artefact numbers and the presence of rich charcoal deposits (Cosgrove et al. 2007; Ferrier 2010). A number of identified endocarp fragments recovered from Urumbal Pocket were dated (refer to Table 1), suggesting a minimum age of ca. 1600 years BP for toxic-nut use at the site. Interpreting the long-term change and continuity in Aboriginal plant use at Urumbal Pocket is difficult, due to the fragmented plant macro-fossil record. It nevertheless appears that tree-nut exploitation has been an important and consistent component of Aboriginal rainforest diet for at least 1000 years. These trends are also reflected in other archaeological sites investigated in the rainforest region: Murubun Shelter, Goddard Creek (Cosgrove et al. 2007), Jiyer Cave and the Mulgrave River sites (Horsfall 1996) (Figure 1).

\section{Discussion}

Palaeoenvironmental reconstructions in the rainforest region demonstrate that in the mid Holocene an extended period of dry conditions and environmental pressures began. It has been suggested that as a response to these environmental changes, Aboriginal people living near or on the rainforest fringe were forced to undertake more frequent journeys into the rainforest as a survival strategy (Ferrier 2010). This interpretation is supported in the archaeological record from Urumbal Pocket and from two other sites investigated in this area-Murubun Shelter and Goddard Creek (Figure 1). The archaeological records from these sites suggest a change from the exploitation of the semi-dry landscape bordering the rainforest region to a more permanent life in the rainforest in the late Holocene (Cosgrove et al.2007). The archaeological record from Urumbal Pocket indicates that increases in Aboriginal activity began to take place around 2000 years ago, accelerating and peaking in the past 1000 years. Before this time, a relatively low level of human occupation occurred at the site. The past 2000 years of Aboriginal occupation at Urumbal Pocket show major increases in cultural remains, including the appearance of incised grinding stones used to process toxic nuts, evidence that points to significant changes in the way Aboriginal people were now exploiting the rainforest environment and its resources. Numbers of plant remains increase dramatically in archaeological deposits dated to the past 1000 years of occupation, a pattern that is reported to be similar in archaeological sites investigated across the rainforest region (Horsfall 1996; Cosgrove et al. 2007). At the time of Aboriginal-European contact, historical accounts demonstrate that varieties of toxic nuts provided a reliable staple food source on the Atherton-Evelyn Tableland during the wet season. Thus, one possibility is that toxic nuts played a significant role in the development of complex semi-sedentary rainforest societies that were recorded at contact, and perhaps also provided the means for large ceremonial gatherings to be held on the Atherton-Evelyn Tablel and during the wet season when large quantities of toxic nuts were consumed (Coyyan 1918).

\section{Conclusion}

Peter Kershaw's pioneering research on the Atherton Tableland in Far North Queensland's tropical rainforest region over the past 40 years has established the importantpalaeoenvironmental backdrop to human-environment interactions on the Atherton Tableland. These include his 
palaeovegetation framework derived from pollen and charcoal studies from Lynch's Crater. We have benefited from this important work, allowing us to investigate the ecological relationships between people and changing subsistence patterns in a unique part of Australia. Results of the analysis on archaeobotanical macro-fossils excavated from the Urumbal Pocket open site in Far North Queensland's Wet Tropics World Heritage Bioregion demonstrate that the application of ethnographic analogy to the archaeological plant remains provides clues to past human subsistence behaviour. By applying this method, we have identified toxic food use that extends back to at least 1600 years ago. Based on the evidence, it appears that Aboriginal people repeatedly collected and processed rainforest walnuts at the Urumbal Pocket site over a period of ca. 1600-2000 years. The evidence also suggests that this subsistence strategy was already in place on a much smaller scale before the shift towards more permanent rainforest occupation sometime in the past 2000 years. This adaptive shift has been interpreted as the outcome of highly unstable ENSO activity beginning about 5000 years ago (Turney and Hobbs 2006; Cosgrove et al. 2007). Our research demonstrates that explanations of cultural change in the mid- to late-Holocene period can be linked to broad-scale environmental changes. Processes of social intensification probably led to a major re-orientation of social, political and economic structures. It also appears that two languages developed during this time, Yidinj in the north and Dyirbal in the south (Dixon 1991:4). This facilitated the emergence of a fully functioning rainforest society that was unique in Aboriginal Australia.

\section{Acknowledgements}

This research was funded by an ARC Discovery Grant DP0210363. La Trobe University provided Ferrier with a scholarship to carry out her $\mathrm{PhD}$ research on the Urumbal Pocket archaeological material. AINSE funded the radiocarbon dating of the nutshell fragments (Research Award 07/034). Radiocarbon determinations were conducted at the Waikato Radiocarbon Laboratory in New Zealand, and we thank Alan Hogg and Fiona Petchey for their assistance. The collection of modern plant specimens were conducted with permission from the Department of Environment and Resource Management Queensland (WISP07417410). All research procedures were approved by the relevant Ethics Committee (Reference Number: 0444). We thank the Jirrbal Aboriginal people in Ravenshoe for granting us permission to excavate the Urumbal Pocket site, and particularly Maisie Barlow for sharing her childhood memories and knowledge with us. We would also like to thank Bruno David and Simon Haberle and two anonymous referees for constructive comments on our paper.

\section{References}

Anderberg, L. 1994. Atlas of Seeds and small fruits of Northwest-European plant species. Swedish Museum of Natural History, Stockholm.

Asmussen, B. 2008. Anything more than a picnic? Re-considering arguments for ceremonial Macrozamia use in mid-Holocene Australia. Archaeology in Oceania 43:93-103.

Asmussen, B. 2009. Another burning question: hunter-gatherer exploitation of Macrozamia spp. Archaeology in Oceania 44:142-9.

Asmussen, B. 2010. In a nutshell: the identification and archaeological application of experimentally defined correlates of macrozamia seed processing. Journal of Archaeological Science 37:2117-25.

Beaton, J. 1983. Does intensification account for change in the Australian Holocene Archaeological record? Archaeology in Oceania 18:94-97.

Beaton, J. 1985. Evidence for a coastal occupation time-lag at Princess Charlotte Bay (North 
Queensland) and implications for coastal colonisation and population growth theories for Aboriginal Australia. Archaeology in Oceania 20:1-20.

Beaton, J. 1990. The importance of past population for prehistory. In: Meehan, B. and White, N. (eds), Hunter-Gatherer Demography: Past and Present. Oceania Monograph 39:23-40.

Beck, W.A., Clarke, A. and Head, L. 1989. Plants in Australian Archaeology, Tempus Vol. 1, Anthropology Museum, University of Queensland, St. Lucia.

Bell, F.C., Winter, J.W., Pahl L.I. and Atherton, R.B. 1987. Distribution, area and tenure of rainforest in northeastern Australia. Proceedings of the Royal Society of Queensland 98:27-39.

Brock, J. 2005. Native Plants of Northern Australia. Reeds Books, Chatswood, NSW.

Clarke, A. 1985. A preliminary archaeobotanical analysis of the Anbanagbanag 1 site. In: Jones, R. (ed), Archaeological research in Kakadu National Park, pp. 77-96. Australian National Parks and Wildlife Service, Special Publication 13.

Clarke, A. 1988. Archaeological and ethnobotanical interpretations of plant remains from Kakadu National Park, Northern Territory. In: Meehan, B. and Jones, R. (eds), Archaeology with ethnography: An Australian perspective, pp. 123-36. Department of Prehistory, Research School of Pacific Studies, Canberra.

Cooper, W. and Cooper, W.T. 2004. Fruits of the Australian Tropical Rainforest. Nokomis Editions Pty Ltd, Melbourne.

Cosgrove, R. 2005. Coping with noxious nuts. Nature Australia 28(6):47-53.

Cosgrove, R. and Allen, J. 2001. Prey Choice and Hunting Strategies in the Late Pleistocene: Evidence from Southwest Tasmania. In: Anderson, A., Lilley, I. and O'Connor, S. (eds), Histories of old ages. Essays in honour of Rhys Jones, pp. 397-429. Research School of Pacific and Asian Studies, ANU.

Cosgrove, R., Field, J. and Ferrier, Á. 2007. The archaeology of Australia's tropical rainforests. Palaeogeography, Palaeoclimatology, Palaeoecology 251:150-73.

Cosgrove, R. and Raymont, E. 2002. Jiyer Cave revisited: preliminary results from northeast Queensland rainforest. Australian Archaeology 54:29-36.

Coyyan (M. O'Leary) 1918. The Aboriginals. Columns I-X. The Northern Herald (The Tablelander).

Denham, T., Fullagar, R. and Head, L. 2009. Plant exploitation in Sahul: From colonisation to the emergence of regional specialization during the Holocene. Quaternary International 202:29-40.

Dixon, R.M.W. 1991. Words of Our Country: Stories, Place Names and Vocabulary in Yidiny. The Aboriginal Language of the Cairns-Yarrabah Region. Queensland University Press.

Ferrier, A. 2010. Journeys into the rainforest. Long-term change and continuity in Aboriginal tropical rainforest occupation on the Evelyn Tableland in far north Queensland. Unpublished $\mathrm{PhD}$ thesis. La Trobe University, Melbourne.

Field, J., Cosgrove, R., Fullagar, R. and Lance, B. 2009. Survival of starch residues on grinding stones in private collections: a study of morahs from the tropical rainforests of $\mathrm{NE}$ Queensland, pp. 228-38. In: Haslam, M., Robertson, G., Crowther, A., Nugent, S. and Kirkwood, L. (eds), Archaeological science under a microscope. Studies in Residue and ancient DNA analysis in Honour of Thomas H. Loy. Terra Australis 30, ANU E Press, Canberra.

Haberle, S. 2005. A 22Ka pollen record from Lake Euramoo, Wet Tropics of NE Queensland, Australia. Quaternary Research 64(3):343-56.

Haberle, S.G. and David, B. 2004. Climates of change: human dimensions of Holocene environmental change in low latitudes of the PEPII transect. Quaternary International 118-9, 165-79.

Harris, D.R. 1975. Traditional patterns of plant-food procurement in the Cape York Peninsula and Torres Strait Islands: report on fieldwork carried out Aug-Nov 1974. 
Harris, D. 1978. Adaptation to a tropical rain-forest environment: Aboriginal subsistence in northeastern Queensland. In: Blurton Jones, N.G. and Reynolds, V. (eds), Human behaviour and adaptation, pp. 113-34. Taylor \& Francis, London.

Harris, D. 1987. Aboriginal subsistence in a tropical rain forest environment: food procurement, cannibalism, and population regulation in northeastern Australia. In: Harris, M. and Ross, E.B. (eds), Food evolution: toward a theory of human food habits, pp. 357-85. Temple University Press, Philadelphia.

Horsfall, N. 1987. Living in rainforest: the prehistoric occupation of North Queensland's humid tropics. Unpublished PhD thesis. James Cook University, Townsville.

Horsfall, N. 1990. People and the rainforest: an archaeological perspective. In: Webb, L.J. and Kikkawa, J. (eds), Australian tropical rainforests: science-values-meaning, pp. 33-9. CSIRO, Melbourne.

Horsfall, N. 1996. Holocene occupation of the tropical rainforests of North Queensland. Tempus Vol. 4, pp. 174-90.

Hyland, B.P.M., Wiffin, T., Christophel, D.C. and Elick, R.W. 2002. Australian Tropical Rain Forest Plants: Trees, Shrubs and Vines. CSIRO Publishing, Melbourne.

Keepax, C. 1977. Contamination of archaeological deposits by seeds of modern origin with particular reference to the use of flotation machines. Journal of Archaeological Science 4:221-9.

Kershaw, A.P. 1986. Climatic change and Aboriginal burning in northeast Australia during the last two glacial/interglacial cycles. Nature 322:47-9.

Lourandos, H. 1997. Continent of hunter-gatherers: new perspectives in Australian prehistory. Cambridge University Press, New York.

Lumholtz, C. 1889. Among Cannibals: account of four years travels in Australia and of camp life with the Aborigines of Queensland. Australian National University Press, Canberra (reprinted 1980).

Martinoli, D. and Jacomet, S. 2004. Identifying endocarp remains and exploring their use at Epipalaeolithic Öküzini in southwest Anatolia, Turkey. Vegetation History and Archaeobotany 13:45-54.

McConnell, K. and O'Connor, S. 1997. 40,000 year record of food plants in the southern Kimberley. Australian Archaeology 45:20-31.

McKenzie, N., Jacquier, D., Isbell, R. and Brown, K. 2004. Australian Soils and Landscapes: An Illustrated Compendium, Melbourne, CSIRO.

Meston, A. 1889. Report of the Government Scientific Expedition to Bellender-Ker Range. Government Printer, Brisbane.

Minnis, P.E. 1981. Seeds in archaeological sites: sources and some interpretive problems. American Antiquity 48(1):143-52.

Mjöberg, E. 1918. Bland Stenåldersmänniskor i Queenslands Vildmarker (Amongst Stone Age People in the Queensland Wilderness). Albert Bonniers Boktryckeri, Stockholm.

Morwood, M.J. and Hobbs, D.R. 1995. Conclusions.In: Morwood, M.J. and Hobbs, D.R. (eds), Quinkan Prehistory: The archaeology of Aboriginal Art in S.E. Cape York Peninsula, Australia. Tempus Vol. 3, pp. 178-85. Archaeology and Material Culture Studies in Anthropology. The University of Queensland, Brisbane.

Moss, P.T. and Kershaw, A.P. 2000. The last glacial cycle from the humid tropics of northeastern Australia: comparison of a terrestrial and a marine record. Palaeogeography, Palaeoclimatology, Palaeoecology 155:155-76.

O'Connell, J. and Allen, J. 2008. Getting from Sunda to Sahul. In: Clark, G., Leach, F. and O'Connor, S. (eds), Islands of Inquiry. Colonisation, seafaring and the archaeology of maritime landscapes, pp. 31-46. Terra Australis 29, ANU E Press. 
Pedley, H. 1992. Aboriginal life in the rainforest. Queensland Department of Education, Brisbane.

Pedley, H. 1993. Plant detoxification in the rainforest: The processing of poisonous plant foods by the Jirrbal-Girramay people. Unpublished MA thesis. Material Culture Unit, James Cook University, Townsville.

Roth, W.E. 1900. Scientific report [to the Under-Secretary, Brisbane] on the natives of the (lower) Tully River, Cooktown.

Roth, W.E. 1901-1910. North Queensland ethnography. Bulletins 1-8. Department of Home Secretary, Brisbane.

Rowland, M. 1999. Holocene environmental variability: have its impacts been underestimated in Australian pre-history? The Artefact 22:11-48.

Smith, M.1982. Late Pleistocene zamia exploitation in southern Western Australia.Archaeology in Oceania 17:117-21.

Smith, M. 1996. Revisiting Pleistocene Macrozamia. Australian Archaeology 42:52-3.

Summerhayes, G.R., Leavesley, M., Fairbairn, A., Mandui, H., Field, J., Ford, A. and Fullagar, R. 2010. Human Adaptation and Plant Use in Highland New Guinea 49,000 to 44,000 Years Ago. Science 330:78-81.

Tuechler, A. 2010. Toxic plant food processing in north-east Queensland's rainforest region. A study in cost-benefit ratio. Unpublished Honours dissertation. La Trobe University.

Turney, C.S.M., Kershaw, A.P., Moss, P., Bird, M.I., Fifield, L.K., Cresswell, R.G., Santos, G.M., Di Tada, M.L., Hausladen, P.A. and Zhou, Y. 2001. Redating the onset of burning at Lynch's Crater (North Queensland): implications for human settlement in Australia. Journal of Quaternary Science 16 (8):767-71.

Turney, C.S.M. and Hobbs, D.R. 2006. ENSO influence on Holocene Aboriginal populations in Queensland, Australia. Journal of Archaeological Science 33:1744-48.

Wallis, L. 2001. Environmental history of northwest Australia based on phytolith analysis at Carpenter's Gap 1. Quaternary International 83-85:103-17.

Wallis, L. 2003. An overview of leaf phytolith production patterns in selected northwest Australian flora. Review of Palaeobotany and Palynology 125:201-48. 